\title{
SYNTHESIS, CHARACTERIZATION AND BIOCOMPATIBILITY OF PLANT-OIL BASED HYDROGELS
}

\author{
Ozlem YALCIN CAPAN ${ }^{1}$, Pinar CAKIR HATIR ${ }^{2 *}$ \\ ${ }^{1}$ Department of Molecular Biology and Genetic, Faculty of Science and Letters, İstanbul Arel University, 34537, \\ Büyükçekmece, Istanbul, TURKEY \\ ${ }^{2}$ Department of Biomedical Engineering, Faculty of Engineering and Architecture, İstanbul Arel University, 34537, \\ Büyükçekmece, Istanbul, TURKEY
}

Cite this article as:

Yalcin Capan O. \& Cakir Hatir P. 2021. Synthesis, characterization and biocompatibility of plant-oil based hydrogels. Trakya Univ J Nat Sci, 22(2): 147-154, DOI: 10.23902/trkjnat.925742

Received: 22 April 2021, Accepted: 10 June 2021, Online First: 25 June 2021, Published: 15 October 2021

\section{Edited by:}

Reşat Unal

*Corresponding Author:

Pinar Cakir Hatir

pinarcakir@arel.edu.tr

\section{ORCID iDs of the authors:}

OYC . orcid.org/0000-0002-3806-7118

PCH. orcid.org/0000-0002-7511-3355

Key words:

Hydrogel

Renewable resources

Biocompatibility

Acrylated methyl ricinoleate

\begin{abstract}
Biocompatible hydrogels are used in a variety of biomedical applications, including tissue scaffolds, drug delivery systems, lab/organ-on-a-chips, biosensors, cell-culture studies and contact lenses. The demand for novel and functional monomers to be used in hydrogel synthesis is increasing as the number of biomedical applications and need for biomaterials increase. The purpose of the study was to develop novel hydrogels from renewable materials. Acrylated methyl ricinoleate, a plant oil-based monomer, was used as the renewable material. The effects of acrylated methyl ricinoleate/N-isopropyl acrylamide molar ratio on hydrogel structural properties, thermal stability and in vitro cytotoxicity were studied. FTIR spectroscopy was used to characterize the structural properties of the hydrogels, while TGA was used to characterize the thermal properties. HEK293 and Cos-7 cell lines were used to test the cytotoxicity of the monomers and hydrogels. $\mathrm{IC}_{50}$ values for acrylated methyl ricinoleate and $\mathrm{N}$ isopropyl acrylamide were found to be greater than $25 \mathrm{mg} / \mathrm{mL}$. Cell viability of hydrogels containing $50 \%$ or more acrylated methyl ricinoleate was greater than $60 \%$, while hydrogel biocompatibility decreased with decreasing molar ratio of acrylated methyl ricinoleate. Cells showed a minimum viability of $80 \%$ when incubated in hydrogel degradation products. An environmentally friendly synthesis method was developed and novel biocompatible hydrogels from renewable materials were produced for biomedical applications.
\end{abstract}

Özet: Biyouyumlu hidrojeller, doku iskeleleri, ilaç taşıyıcı sitemler ve biyosensörler dahil olmak üzere çeşitli biyomedikal uygulamalarda kullanılmaktadırlar. Biyomedikal uygulamaların sayısı ve biyomalzemelere olan ihtiyaç arttıkça hidrojel sentezinde kullanılacak yeni ve işlevsel monomerlere olan talep artmaktadır. Çalıșmanın amacı, yenilenebilir malzemelerden özgün hidrojeller geliştirmektir. Yenilenebilir malzeme olarak bitkisel yağ bazlı bir monomer olan akrillenmiş metil risinoleat kullanılmıştır. Akrillenmiş metil risinoleat / Nizopropil akrilamid mol oranının hidrojellerin yapısal özellikleri, termal dayanıklılıkları ve in vitro sitotoksisiteleri üzerindeki etkileri incelenmiştir. Hidrojellerin yapısal özelliklerini karakterize etmek için FTIR spektroskopisi kullanılırken, termal özellikleri karakterize etmek için TGA kullanılmıştır. HEK293 ve Cos-7 hücre hatları, monomerlerin ve hidrojellerin sitotoksisitesini test etmek için kullanılmıștır. Akrillenmiş metil risinoleat ve N-izopropil akrilamid için $\mathrm{IC}_{50}$ değerlerinin $25 \mathrm{mg} / \mathrm{mL}$ 'den büyük olduğu bulunmuştur. $\% 50$ veya daha fazla akrillenmiş metil risinoleat içeren hidrojellerin hücre canlılığı \%60'ın üzerinde iken, hidrojellerin biyouyumluluğu, akrillenmiş metil risinoleatın hidrojel içerisindeki mol oranı azaldıkça azalmaktadır. Hücreler, hidrojellerin bozunma ürünlerinde inkübe edildiklerinde minimum \%80 canl1l1k göstermiştir. Sonuç olarak, çevre dostu bir sentez yöntemi geliştirilmiş olup, biyomedikal uygulamalarda kullanılmak üzere yenilenebilir malzemelerden özgün biyouyumlu hidrojeller üretilmiştir.

\section{Introduction}

Hydrogels are crosslinked three-dimensional natural and synthetic polymer networks with hydrophilic properties that can absorb a significant amount of water. Because of their similarity to living tissues, they can be used in a variety of biomedical applications, including drug-delivery systems (Peers et al. 2020), scaffolds (Xu et al. 2019), lab/organ-on-a-chips (Ding et al. 2020), cellculture studies (Bhattacharya et al. 2012) and contact lenses 
(Peppas \& Hoffman 2020). Hydrogels swell in aqueous media because their network structures contain hydrophilic polymers. Depending on the intended application, the swelling profiles of hydrogels may be altered by using more or less hydrophilic monomers. Hydrogels are frequently designed using acrylic-based monomers such as hydroxyethyl methacrylate and methyl methacrylate (Peppas et al. 2000). Furthermore, poly(ethylene oxide) (PEO) and poly(ethylene glycol) (PEG) based hydrogels are gaining popularity due to their biocompatibility and FDA approval. Poly-lactic or glycolic acids are also used in the production of hydrogels, especially for biodegradable systems (Lee \& He 2010). Smart hydrogels can also be produced using various monomers such as poly(acrylic acid), poly (methacrylic acid), and poly(vinyl alcohol) (Nisopropyl acrylamide). pH-responsive hydrogel systems are created using acidic and basic monomers (Koetting et al. 2015), while thermoresponsive hydrogels are created using N-isopropyl acrylamide (NIPAM) (Dong \& Hoffman 1986). Smart hydrogels are stimuli-responsive hydrogels that can respond to external stimuli by changing their structural conformations and swelling-deswelling behaviors. Several monomers are needed to create novel hydrogels with desired hydrophilicity for a variety of applications. Thus, there will always be a need for novel and functional monomers.

One of the top priorities of researchers is to synthesize functional monomers and novel hydrogels while minimizing environmental impact. Therefore, environmentally friendly green raw materials are favored for the production of monomers and polymers. Plant oilbased materials are often used as renewable resources because they contain a large number of functionalizable hydroxyl groups. Furthermore, fatty acids contain double bonds that are easily converted into epoxy groups, resulting in a variety of reactions with ring-opening reagents to synthesize biocompatible polymers (Miao et al. 2014). Castor oil, for example, is one of the most popular naturally functionalized plant oil triglycerides as it can be used to create a variety of functional monomers (Dupé et al. 2012).

Several studies have been performed on the synthesis of hydrogels from plant-based renewable materials such as lignocelluloses, polysaccharides, and proteins (Mohammadinejad et al. 2019) but there are few examples of plant oil-based hydrogel synthesis. Sebacic acid, for example, was used as a fatty acid in the design of hydrogels for biomedical applications (Guo et al. 2011). In a recent study, acrylated methyl ricinoleate (AMR), a castor oil monomer, was used to create thermoresponsive hydrogels on glass surface for use in biochips, biosensors, and lab-ona-chip applications (Cakir Hatir \& Cayli 2019). Another recent study demonstrated that bacterial cellulose and castor oil could be successfully combined to create thermoresponsive hydrogels (Isikci Koca et al. 2020). In the present study, we aimed to synthesize and characterize novel biocompatible hydrogels derived from renewable resources. We used AMR as the plant-oil based monomer, NIPAM as thermoresponsive monomer and N,N'-
Methylenebis (acrylamide) (MBA) as crosslinker. We varied the molar ratio of AMR/NIPAM and evaluated the effects of AMR on structural properties, thermal stability, and in vitro cytotoxicity of hydrogels. We developed a green, environmentally friendly synthesis process in order to create biocompatible hydrogels.

\section{Materials and Methods}

\section{Materials}

N,N'-Methylenebis(acrylamide) (MBA), 2,2-dimethoxy-2phenylacetophenone (DMPA) and N-Isopropylacrylamide (NIPAM) were supplied from Sigma Aldrich. Acrylated methyl ricinoleate was synthesized as described before (Cakir Hatir \& Cayli 2019). Distilled water was obtained by using Merck Millipore. Solvents were supplied from Sigma Aldrich. PhotoLab Eliza Plate Reader (AMR-100 Microplate) was used to perform cell viability studies. MMM Vacucell vacuum oven was used to dry hydrogels. Photopolymerization reactions were performed under UV light, UVGL-58 $230 \mathrm{~V}, 50 \mathrm{~Hz}$ lamp at 365 $\mathrm{nm}$ wavelength. Structural characterizations of polymers were performed by using JASCO FT/IR-6000 Spectrometer. Thermal characterizations were carried out by using HITACHI STA7200 Simultaneous TGA.

\section{Synthesis of hydrogels}

Hydrogels were synthesized by using the photopolymerization method with a radical initiator, DMPA, under UV irradiation at $365 \mathrm{~nm}$. MBA $(1.25 \mathrm{mg})$ and NIPAM (Table 1) were weighed in a vial and dissolved in $400 \mu 1$ of Phosphate Buffered Saline (PBS). AMR and DMPA (1\% with respect to the total number of double bonds in the system) were transferred into the solution. All polymerization reactions were performed under UV irradiation at $365 \mathrm{~nm}$ for $60 \mathrm{~min}$ at $25^{\circ} \mathrm{C}$. After the polymerization, the hydrogels were washed with water and methanol to remove unreacted monomers and kept in vacuum oven at $25^{\circ} \mathrm{C}$ for 24 hours.

\section{Characterization of hydrogels}

The hydrogels were characterized by Fourier Transform Infrared Spectroscopy (FTIR) and Simultaneous Thermogravimetric Analyzer (TGA). Structural characterization was performed by using JASCO 6600 spectrophotometer in the range of 400-4000 $\mathrm{cm}^{-1}$. All samples were scanned 32 times and FTIR spectra were obtained with $4 \mathrm{~cm}^{-1}$ resolution. Thermal characterization was carried out by HITACHI STA7200 TGA. TGA analyses were carried out under nitrogen atmosphere at a rate of $200 \mathrm{~mL} / \mathrm{min}$ with a heating rate of $10^{\circ} \mathrm{C} / \mathrm{min}$ from $0^{\circ} \mathrm{C}$ to $900^{\circ} \mathrm{C}$.

Table 1. Hydrogels synthesized by using different ratios of MBA, AMR and NIPAM.

\begin{tabular}{cccc}
\hline \hline & \multicolumn{3}{c}{ Molar equivalencies of monomers } \\
\cline { 2 - 4 } Hydrogels & MBA & AMR & NIPAM \\
\hline \hline H1 & 1 & 100 & - \\
H2 & 1 & 80 & 20 \\
H3 & 1 & 50 & 50 \\
H4 & 1 & 20 & 80 \\
H5 & 1 & - & 100 \\
\hline \hline
\end{tabular}




\section{In vitro cytotoxicity assays of monomers and hydrogels}

Cytotoxicity assays were performed by using Cos-7 (African green monkey kidney fibroblast-like cell line) and HEK293 cells (Human Embryonic Kidney Cells). The cells were cultured in a complete culture medium consisting of Dulbecco's Modified Eagle Medium (DMEM) supplemented with $2 \mathrm{mM}$ L-Glutamine (Thermo Fisher), $100 \mathrm{IU} / \mathrm{mL}$ penicillin-streptomycin (Thermo Fisher) and $10 \%$ fetal bovine serum (FBS, Lonza ${ }^{\circledR}$ ). Cos-7 and HEK293 cells were seeded in 96-well cell culture plates at $10 \times 10^{3}$ cells/well and then incubated at $37^{\circ} \mathrm{C}$ in $5 \% \mathrm{CO}_{2}$. After $24 \mathrm{~h}$ of incubation, $100 \mu \mathrm{L}$ of different concentrations (0.5-1-2-5-10 mg/mL) of monomers in PBS or only PBS as control were added to the wells. For cytotoxicity assay of hydrogels, $14 \times 10^{4}$ cells/well Cos-7 or HEK293 cells were seeded in 24-well plates which were previously covered with different concentrations of hydrogels. All experiments were carried out in triplicates. After a further incubation for $24 \mathrm{~h}$, cytotoxicity of monomers and hydrogels was measured by the MTT (3-(4,5-Dimethylthiazol-2-yl)-2,5diphenyltetrazolium bromide) assay.

The MTT cytotoxicity assay is a colorimetric assay that measures the number of living cells which have active enzymes converting yellow tetrazolium salt into insoluble purple formazan. The intensity of the purple color is directly proportional to the metabolically active living cells and assessed by colorimetric analysis.

For MTT assay, $10 \mu \mathrm{L}$ and $100 \mu \mathrm{L}$ of sterilized MTT $(5 \mathrm{mg} / \mathrm{mL})$ reagent was added to each 96 -well and 24 well, respectively. After incubation of plates at $37^{\circ} \mathrm{C}$ in $5 \% \mathrm{CO}_{2}$ for $4 \mathrm{~h}$, the MTT solution was removed. Purple color formazan products were dissolved in Dimethyl Sulphoxyde (DMSO) by incubating the plates in the dark for $15 \mathrm{~min}$ on an orbital shaker. Purple color with an absorbance at $570 \mathrm{~nm}$ was measured by using an Eliza Plate Reader. Percentage of cell viability was calculated by taking the ratio of absorbance values for samples and control and multiplied by 100 .

\section{In vitro cytotoxicity assays of degradation products}

$20 \mathrm{mg}$ of hydrogel was weighed and transferred into 1 $\mathrm{mL}$ of $0.1 \mathrm{~N} \mathrm{NaOH}$ solution and incubated at room temperature for $24 \mathrm{~h}$. After the hydrogels were degraded entirely, the $\mathrm{pH}$ of the solution was adjusted to 7.4. The solution was filtered to sterilize, afterwards, it was diluted 2, 10 and 100 times with cell culture media. $100 \mu 1$ of the diluted solutions were transferred to the 96-well plates containing cultured Cos-7 cells and incubated for $24 \mathrm{~h}$ at $37^{\circ} \mathrm{C}$. Cytotoxicity of the degraded products was evaluated using the MTT assay.

\section{Statistical analysis}

For cell viability assays, all experiments were performed as two independent experiments carried out in triplicates. All results are presented as mean \pm standard deviation (SD). Statistical significance between different groups were evaluated by using one-way analysis of variance (ANOVA) with Bonferroni correction for post hoc analysis and $\mathrm{p}<0.05$ was considered as significant.

\section{Results}

\section{Characterization of hydrogels}

FTIR spectra of the hydrogels are shown in Fig. 1. Hydrogels, including AMR have a strong peak at 1727 $\mathrm{cm}^{-1}$. Hydrogels synthesized with NIPAM have bands at $1646 \mathrm{~cm}^{-1}(\mathrm{H} 3, \mathrm{H} 4), 1631 \mathrm{~cm}^{-1}(\mathrm{H} 5)$, and $1535 \mathrm{~cm}^{-1}(\mathrm{H} 3$, $\mathrm{H} 4, \mathrm{H} 5)$. $\mathrm{H} 4$ and $\mathrm{H} 5$ have broad bands at $3292 \mathrm{~cm}^{-1}$. Hydrogels synthesized with AMR have bands at $2923 \mathrm{~cm}^{-}$ 1 and $2854 \mathrm{~cm}^{-1}$, whereas hydrogels without AMR have the same bands at around $2969 \mathrm{~cm}^{-1}$ and $2928 \mathrm{~cm}^{-1}$.

TGA curves are shown in Fig. 2. Experiments were carried out under a nitrogen atmosphere at a rate of 200 $\mathrm{mL} / \mathrm{min}$ with a heating rate of $10^{\circ} \mathrm{C} / \mathrm{min}$ from 0 to $900^{\circ} \mathrm{C}$. Hydrogel $\mathrm{H} 1$ exhibits a decomposition between $300^{\circ} \mathrm{C}$ and $500^{\circ} \mathrm{C}$ and lost $85 \%$ of its weight around $320^{\circ} \mathrm{C}$. TGA curves of $\mathrm{H} 2$ and $\mathrm{H} 4$ show roughly $10 \%$ weight loss at $274^{\circ} \mathrm{C}$ and $55 \%$ weight loss at $300^{\circ} \mathrm{C}$. TGA curve of $\mathrm{H} 3$ exhibits three significant segmental losses. H5 lost $12 \%$ of its weight between $30^{\circ} \mathrm{C}$ and $200^{\circ} \mathrm{C}$. Two critical parameters, $5 \%$ weight loss temperature and $50 \%$ weight loss temperature, were also investigated (Table 2). The 5\% weight loss temperatures were determined as $240^{\circ} \mathrm{C}$, $212^{\circ} \mathrm{C}, 216^{\circ} \mathrm{C}, 268^{\circ} \mathrm{C}$ and $347^{\circ} \mathrm{C}$ for $\mathrm{H} 1, \mathrm{H} 2, \mathrm{H} 3, \mathrm{H} 4$ and $\mathrm{H} 5$, respectively, whereas the $50 \%$ weight loss temperatures were determined as $344^{\circ} \mathrm{C}, 339^{\circ} \mathrm{C}, 335^{\circ} \mathrm{C}$, $348^{\circ} \mathrm{C}$ and $403^{\circ} \mathrm{C}$ for $\mathrm{H} 1, \mathrm{H} 2, \mathrm{H} 3, \mathrm{H} 4$ and $\mathrm{H} 5$, respectively.

In vitro cytotoxicity assays of monomers and hydrogels

The results of the cytotoxicity assay of AMR, NIPAM and MBA monomer solutions with concentrations ranging from $0.5 \mathrm{mg} / \mathrm{mL}$ to $10 \mathrm{mg} / \mathrm{mL}$ were shown in Fig. 3. Both Cos-7 and HEK293 cells display at least $70 \%$ viability in the presence of a wide range of concentrations (0.5-5 $\mathrm{mg} / \mathrm{mL}$ ) of AMR and NIPAM monomer solutions, whereas a significant reduction in cellular viability (less than 70\%) was detected with $10 \mathrm{mg} / \mathrm{mL}$ concentrations. The toxicity of MBA monomer solution, on the other hand, is significantly high even with $1 \mathrm{mg} / \mathrm{mL}$ concentration, less than $50 \%$. $\mathrm{IC}_{50}(50 \%$ cell growth inhibition) values were also calculated by using the curve constructed by plotting cell viability $(\%)$ versus monomer concentration $(\mathrm{mg} / \mathrm{mL})$. As shown in Table $3, \mathrm{IC}_{50}$ values of AMR and NIPAM solutions are higher than $25 \mathrm{mg} / \mathrm{mL}$ while $\mathrm{MBA} \mathrm{IC}_{50}$ values are very low, ranging between $1.06 \mathrm{mg} / \mathrm{mL}$ and 0.05 $\mathrm{mg} / \mathrm{mL}$ in Cos-7 and HEK293 cells, respectively.

Table 2. Thermal properties of the hydrogels.

\begin{tabular}{lccccc}
\hline \hline Critical parameters & H1 & H2 & H3 & H4 & H5 \\
\hline $\begin{array}{l}\text { 5\% weight loss } \\
\text { temperature }\left({ }^{\circ} \mathbf{C}\right)\end{array}$ & 240 & 212 & 216 & 268 & 347 \\
$\begin{array}{l}\mathbf{5 0 \%} \text { weight loss } \\
\text { temperature }\left({ }^{\circ} \mathbf{C}\right)\end{array}$ & 344 & 339 & 335 & 348 & 403 \\
\hline \hline
\end{tabular}




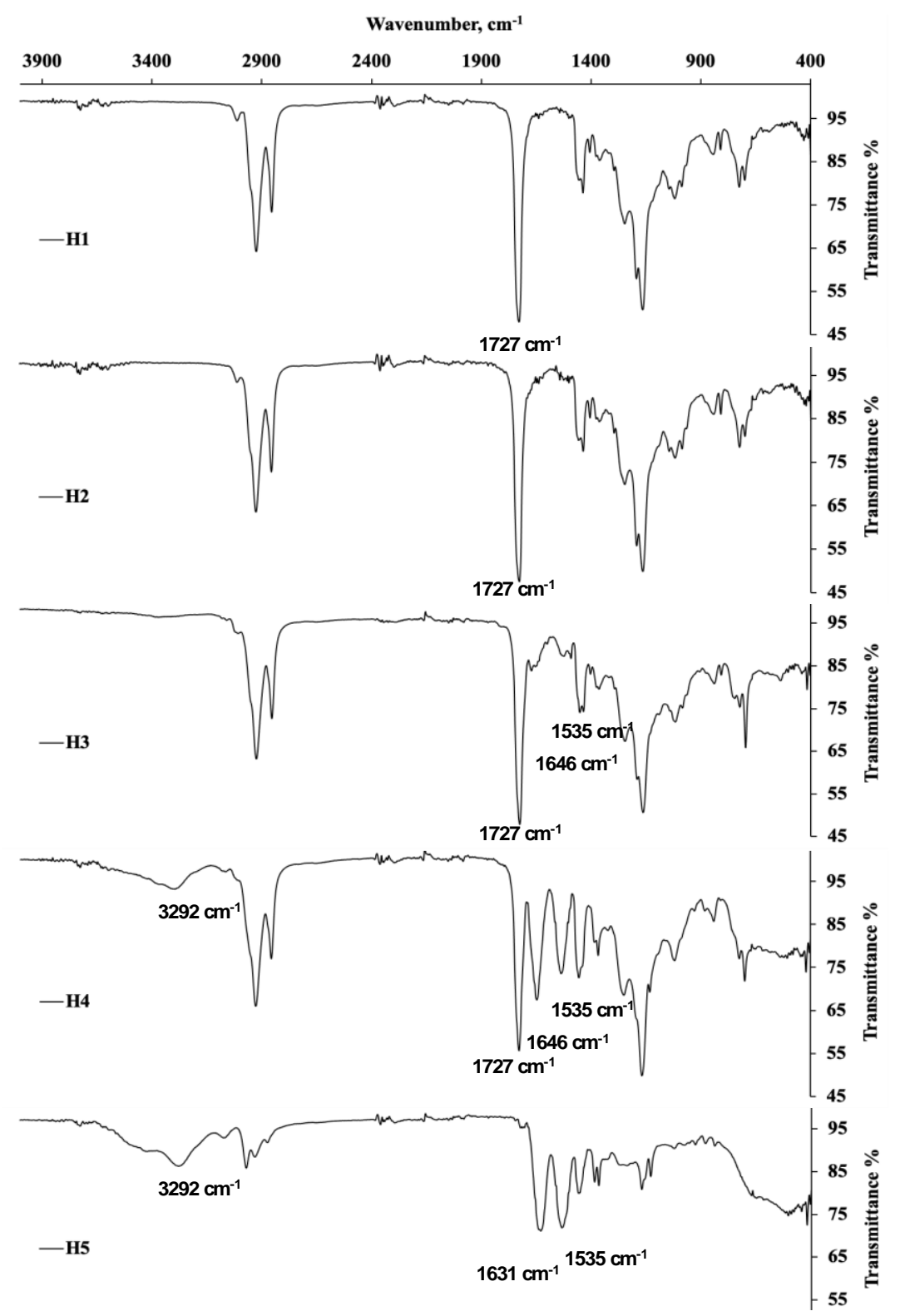

Fig. 1. FTIR spectra of the hydrogels.

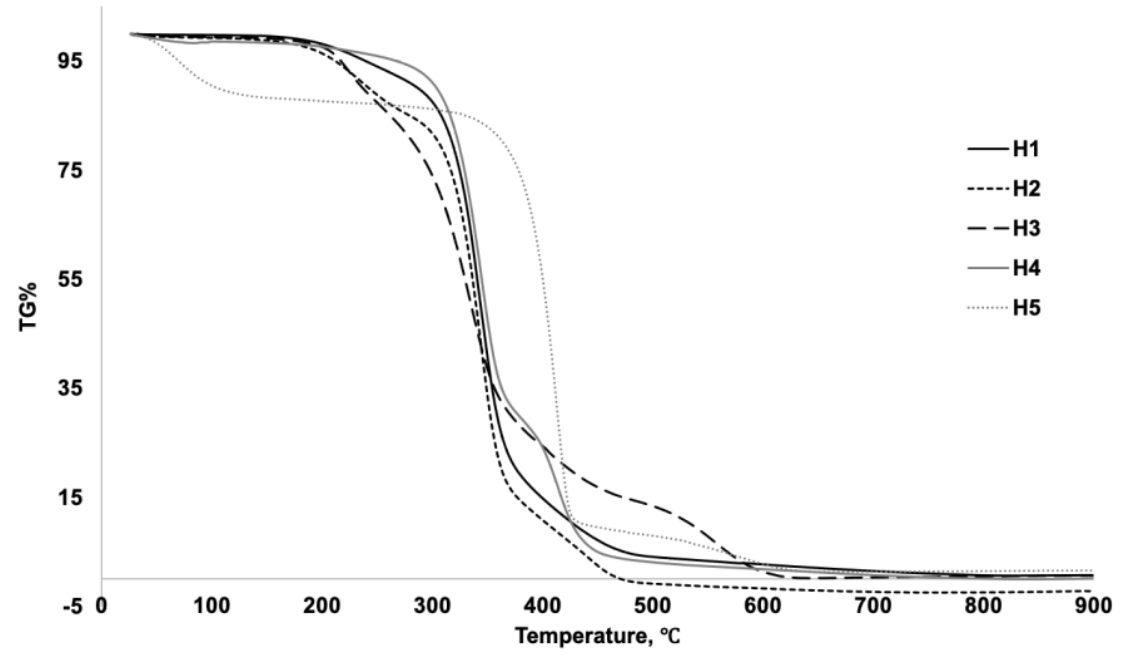

Fig. 2. TGA Curves of the hydrogels. 

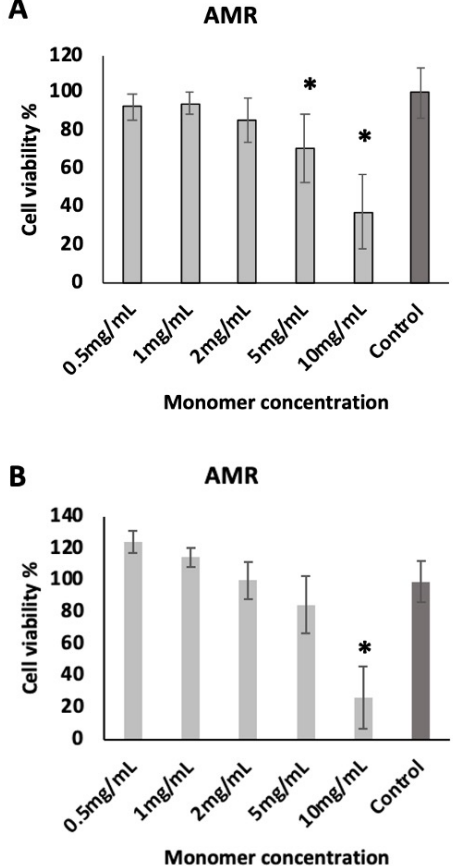

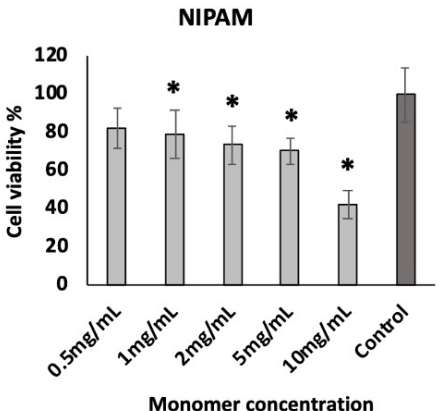

NIPAM

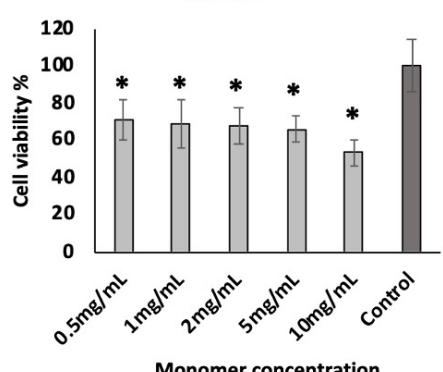

MBA

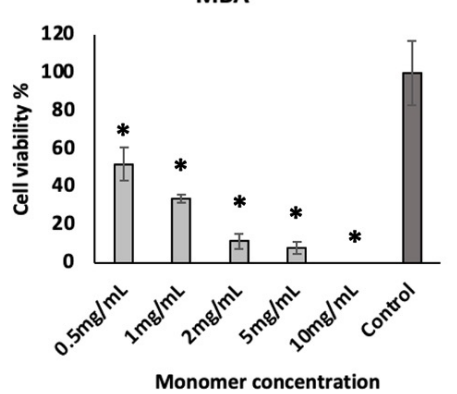

MBA

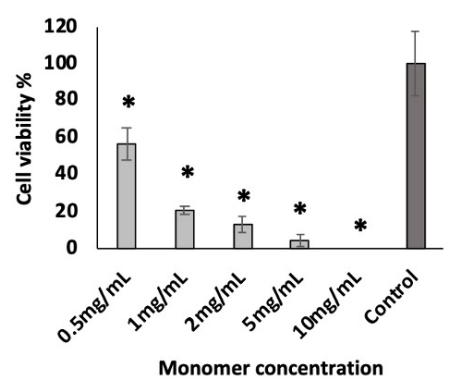

Fig. 3. Cell viability results of two different cell lines (A) Cos-7 and (B) HEK293 with different monomers. Data are presented as mean $\pm \mathrm{SD}$ of two independent experiments conducted as triplicates. Significant differences between each monomer concentration and the control were evaluated using the one-way analysis of variance (ANOVA) followed by Bonferroni post hoc test. Asterisks (*) indicate a significance difference compared to the control; $p<0.05$ after Bonferroni correction.

Cos-7

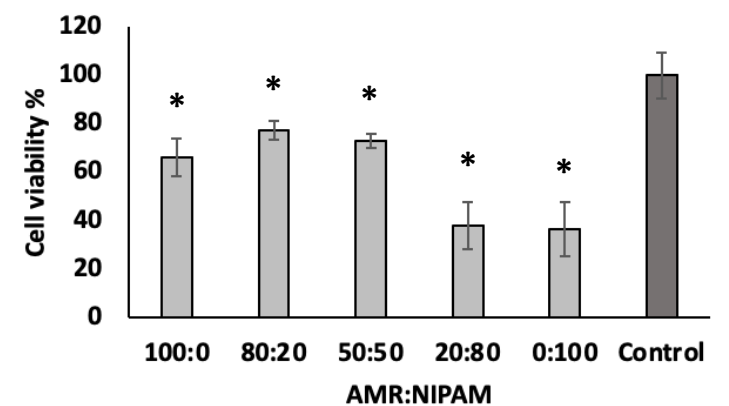

HEK293

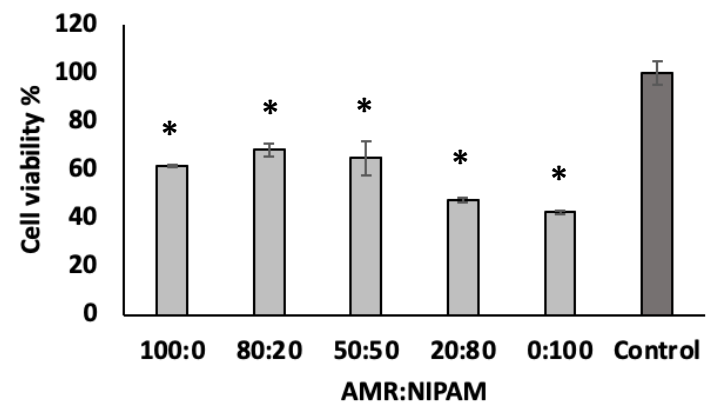

Fig. 4. Cell viability results of two different cell-lines (Cos-7 and HEK293) with different hydrogels. Data are presented as mean \pm SD of two independent experiments, conducted as triplicates. Significant differences between each hydrogel and the control were evaluated using the one-way analysis of variance (ANOVA) followed by Bonferroni post hoc test. Asterisks (*) indicate a significance difference compared to the control; $\mathrm{p}<0.05$ after Bonferroni correction.

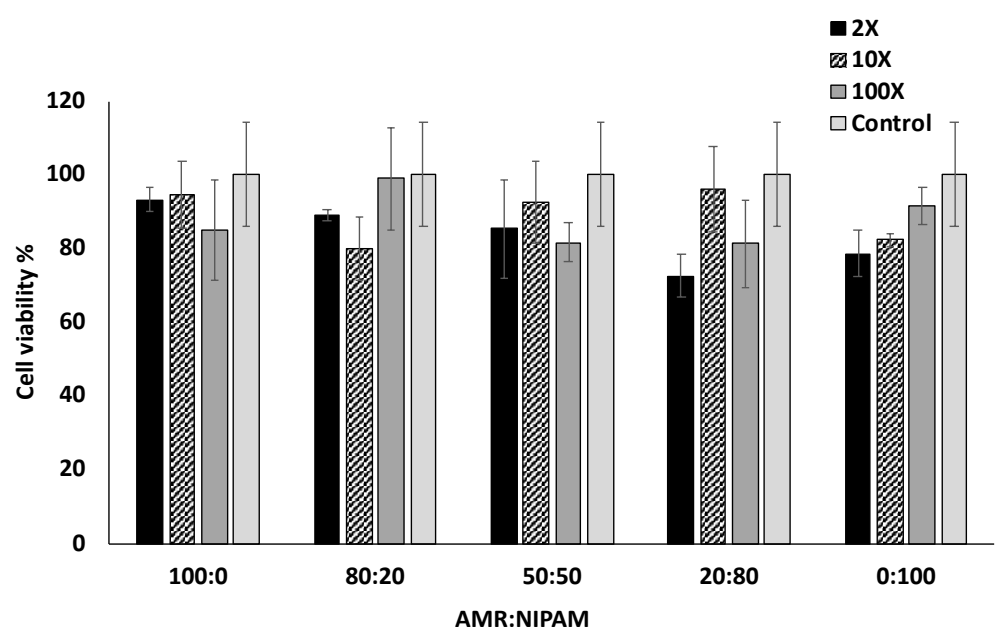

Fig. 5. Cell viability results of the degradation products with different concentrations carried out in Cos-7 cells. Data are presented as mean $\pm \mathrm{SD}$ of two independent experiments conducted as triplicates. 
As shown in Fig. 4, cytotoxicity assay for hydrogels on two different cell lines revealed that the viability of the cells was more than $60 \%$ in hydrogels with varied molar ratios of AMR:NIPAM (100:0, 80:20 and 50:50). However, as the amount of NIPAM in hydrogels (AMR:NIPAM, 80:20 and 0:100) increased, a reduction in cell viability was detected. The hydrogels made up of solely NIPAM monomers showed less than $45 \%$ cell viability in both cell lines.

\section{In vitro cytotoxicity assays of degradation products}

Cytotoxicity of degraded hydrogels with different ratios of AMR:NIPAM was analyzed by MTT assay. Hydrogels were kept in $0.1 \mathrm{~N} \mathrm{NaOH}$ solution at room temperature for $24 \mathrm{~h}$ until they are all degraded. Filtered solutions diluted by 2,10 and 100 times with cell culture media were applied to Cos-7 cells for $24 \mathrm{~h}$. As shown in Fig. 5, cells showed more than $70 \%$ viability when exposed to degraded products in different concentrations supporting the biocompatibility of the hydrogels.

Table 3. $\mathrm{IC}_{50}$ values for Cos-7 and HEK 293 cells treated with AMR, NIPAM and MBA monomer solution.

\begin{tabular}{ccc}
\hline \hline \multirow{2}{*}{ Monomers } & \multicolumn{2}{c}{ IC50 $(\mathrm{mg} / \mathrm{mL})$} \\
& Cos-7 & HEK293 \\
\hline \hline AMR & 30.04 & 47.71 \\
NIPAM & 53.65 & 25.25 \\
MBA & 1.06 & 0.05 \\
\hline \hline
\end{tabular}

\section{Discussion}

Hydrogels generated from natural polymers have attracted significant interest in the field of tissue engineering in recent years due to their low cost of production, biocompatible structure, biodegradability and extracellular matrix mimicking capabilities (Geckil et al. 2010, Ko et al. 2010, Mantha et al. 2019). In this study, novel hydrogels were synthesized using a plant-based monomer (AMR) and a thermoresponsive monomer (NIPAM). The structural and thermal properties of these hydrogels and their effects on cell growth were examined for the first time.

In the first step of the study, FTIR spectra of the hydrogels were evaluated (Fig. 1). AMR has formerly been shown to exhibit two independent ester carbonyl peaks at $1739 \mathrm{~cm}^{-1}$ and $1722 \mathrm{~cm}^{-1}$ prior to polymerization (Cakir Hatir \& Cayli 2019). In the present study, AMR showed two peaks at around $1637 \mathrm{~cm}^{-1}$ and $1620 \mathrm{~cm}^{-1}$ that indicate acrylate double bonds. The absence of these peaks in hydrogels in the former study suggests that acrylate double bonds were consumed during polymerization. Moreover, hydrogels exhibit a strong peak at $1727 \mathrm{~cm}^{-1}$ instead of two separate ester carbonyl peaks, as saturated ester moieties were produced due to polymerization of the acrylate groups. So, the FTIR peaks of the two ester groups shifted to $1727 \mathrm{~cm}^{-1}$, and one ester carbonyl was detected instead of two peaks. These results proved that AMR was involved in the polymerization processes. To establish that NIPAM was also involved in polymerization, the FTIR spectra of NIPAM were analyzed before and after the reactions. The FTIR spectrum of NIPAM revealed a strong peak at around $3280 \mathrm{~cm}^{-1}$ caused by N-H stretching of secondary amide, which formed a broad band following monomer polymerization (Ilić-Stojanović et al. 2013, Isikci Koca et al. 2020). These broad bands are seen in the FTIR spectra of $\mathrm{H} 4$ and $\mathrm{H} 5$. The broad bands contain both $\mathrm{O}-\mathrm{H}$ stretching caused by absorbed water, as proven by TGA data and N-H stretching of secondary amide. Furthermore, there is a peak at $1616 \mathrm{~cm}^{-1}$ caused by the $\mathrm{C}=\mathrm{C}$ bond, which should not be seen in polymer spectra (Shah et al. 2013). NIPAM hydrogels do not display this peak, instead, they exhibit the bands at $1646 \mathrm{~cm}^{-1}$ and $1539 \mathrm{~cm}^{-1}$ indicating $\mathrm{C}=\mathrm{O}$ (amide I) and $\mathrm{N}-\mathrm{H}$ (amide II) stretching, respectively. $\mathrm{H} 3$ and $\mathrm{H} 4$ have peaks at 1646 $\mathrm{cm}^{-1}$ (H3, H4), H5 has a peak at $1631 \mathrm{~cm}^{-1}$ caused by amide I stretching. The bands at around $2950 \mathrm{~cm}^{-1}$ represent vibrations of $-\mathrm{CH}_{3}$ and $-\mathrm{CH}_{2}$. The FTIR spectra confirms that $\mathrm{H} 1$ has AMR, $\mathrm{H} 5$ has NIPAM and $\mathrm{H} 2, \mathrm{H} 3$ and H4 have both NIPAM and AMR. Furthermore, increasing intensity of amide I and amide II bands confirm the increasing molar ratio of NIPAM from $\mathrm{H} 2$ to $\mathrm{H} 5$. The hydrogels synthesized with AMR have bands at $2923 \mathrm{~cm}^{-}$ 1 and $2854 \mathrm{~cm}^{-1}$, whereas the hydrogels without AMR have the same bands at around $2969 \mathrm{~cm}^{-1}$ and $2928 \mathrm{~cm}^{-1}$. Additionally, $\mathrm{H} 4$ and $\mathrm{H} 5$ have broad bands at around 3292 $\mathrm{cm}^{-1}$ which represent $\mathrm{NH}$ stretching of NIPAM. In the spectrum of $\mathrm{H} 3$, the broad band can barely be seen at around $3300 \mathrm{~cm}^{-1}$. On the other hand, $\mathrm{H} 2$ does not have a clear band since the molar ratio of NIPAM is relatively low.

In the next step, the thermal stability properties of the hydrogels were investigated by TGA curves (Fig. 2). Hydrogel H1, synthesized from AMR, exhibited a decomposition between $300^{\circ} \mathrm{C}$ and $500^{\circ} \mathrm{C}$. $\mathrm{H} 1$ lost $85 \%$ of its weight around $320^{\circ} \mathrm{C}$, which might be due to the dissociation of the MR moiety from the main chain (Cakir Hatir \& Cayli 2019). TGA curves of H2 and H4 show roughly $10 \%$ weight loss at $274^{\circ} \mathrm{C}$ and $55 \%$ weight loss at $300^{\circ} \mathrm{C}$, respectively. Decomposed sections of $\mathrm{H} 2$ and $\mathrm{H} 4$ are proportional to the amount of NIPAM used in the polymerization phase. TGA data of $\mathrm{H} 2$ and $\mathrm{H} 4$ revealed that when monomers are combined in differing molar ratios, the polymer is produced as a building block. TGA curve of $\mathrm{H} 3$ shows three major segmental losses, indicating that the crosslinked polymer network was created in the presence of homogeneously dispersed monomers. H5, produced only using NIPAM, lost $12 \%$ of its weight between $30^{\circ} \mathrm{C}$ and $200^{\circ} \mathrm{C}$, indicating evaporation of volatile compounds such as water (Ribeiro et al. 2017). H5 is also thermally stable with only a single decomposition step between $340^{\circ} \mathrm{C}$ and $440^{\circ} \mathrm{C}$, as reported in the literature (Ruiz-Rubio et al. 2015). Temperatures for $5 \%$ and $50 \%$ weight loss were investigated (Table 2 ). The $5 \%$ weight loss temperatures were determined as $240^{\circ} \mathrm{C}, 212^{\circ} \mathrm{C}, 216^{\circ} \mathrm{C}, 268^{\circ} \mathrm{C}$ and $347^{\circ} \mathrm{C}$ for $\mathrm{H} 1, \mathrm{H} 2, \mathrm{H} 3, \mathrm{H} 4$ and $\mathrm{H} 5$, respectively, whereas 
the $50 \%$ weight loss temperatures were determined as $344^{\circ} \mathrm{C}, 339^{\circ} \mathrm{C}, 335^{\circ} \mathrm{C}, 348^{\circ} \mathrm{C}$ and $403^{\circ} \mathrm{C}$ for $\mathrm{H} 1, \mathrm{H} 2, \mathrm{H} 3$, $\mathrm{H} 4$ and $\mathrm{H} 5$, respectively. Among all hydrogels, H5 showed the highest temperature for both 5\% and 50\% weight loss. H1, having only AMR has relatively high temperatures for both $5 \%$ and $50 \%$ weight loss. On the other hand, the combination of AMR and NIPAM caused a slight decrease at the $5 \%$ weight loss temperature. From $\mathrm{H} 2$ to $\mathrm{H} 5$, it was observed that as the molar ratio of NIPAM increases, the temperature for the $5 \%$ weight loss increases as well. However, there is no significant change at the $50 \%$ weight loss temperatures.

As the hydrogels, which consist of AMR, NIPAM and MBA, can be used for tissue engineering, biocompatibility is crucial for in vivo application. Therefore, we evaluated the cytotoxicity of these monomers and hydrogels with different ratios of AMR and NIPAM. As cytotoxic effects may vary for different cell types with different origins, two different cell lines (Cos-7, kidney fibroblast and HEK293, embryonic kidney cells) were used to evaluate cell viability (Capella $e t$. al. 2019). We also calculated the $\mathrm{IC}_{50}$ values for each monomer in Cos-7 and HEK293 cell lines (Table 3). IC 50 values of AMR and NIPAM are higher than $25 \mathrm{mg} / \mathrm{mL}$ while MBA $\mathrm{IC}_{50}$ values are very low, ranging between $1.06 \mathrm{mg} / \mathrm{mL}$ and $0.05 \mathrm{mg} / \mathrm{mL}$ in Cos-7 and HEK293 cells, respectively. According to the results, MBA has the lowest $\mathrm{IC}_{50}$ value compared to AMR and NIPAM in both cell lines, indicating a high cytotoxic effect for the cells. NIPAM and AMR produced comparable $\mathrm{IC}_{50}$ values in which AMR has higher $\mathrm{IC}_{50}$ with HEK293 cells, whereas NIPAM has higher $\mathrm{IC}_{50}$ with Cos-7 cells.

In addition to the cytotoxicity of monomers, hydrogels were tested as well. The cells grown on hydrogels with increased AMR molar ratio exhibited a higher viability compared to the cells grown on hydrogels with increased NIPAM ratio. Cell viability of hydrogels containing $50 \%$ or more AMR was found to be greater than $60 \%$, while biocompatibility of hydrogels reduced with decreasing molar ratio of AMR. The hydrogels made up of only NIPAM showed less than $45 \%$ cell viability in both cell lines.

Although building blocks and hydrogels are biocompatible, we also analyzed the cell viability in the

\section{References}

1. Bhattacharya, M., Malinen, M.M., Lauren, P., Lou, Y.R., Kuisma, S.W., Kanninen, L., Lille, M., Corlu, A., GuGuenGuillouzo, C., Ikkala, O., Laukkanen, A., Urtti, A. \& Yliperttula, M. 2012. Nanofibrillar cellulose hydrogel promotes three-dimensional liver cell culture. Journal of controlled release, 164(3): 291-298.

2. Cakir Hatir, P. \& Cayli, G. 2019. Environmentally friendly synthesis and photopolymerization of acrylated methyl ricinoleate for biomedical applications. Journal of Applied Polymer Science, 136(38): 47969-47976.

3. Capella, V., Rivero, R.E., Liaudat, A.C., Ibarra, L.E., Roma, D.A., Alustiza, F., Mañas, F., Barbero, C.A., Bosch, presence of degradation products. Cells showed a minimum $80 \%$ of viability when they were incubated in degradation products of hydrogels with high molar ratio of AMR (AMR:NIPAM, 100:0, 80:20, 50:50). Therefore, our results indicate that plant oil-based AMR does not lead to cytotoxicity and can be used in tissue engineering applications. However, a longer exposure of hydrogels and degradation products may confirm reliability of the application.

In conclusion, a green, environmentally friendly synthesis method was successfully developed to design biocompatible hydrogels. A plant oil-based monomer, AMR, was used to synthesize novel hydrogels. Molar ratio of AMR to NIPAM was varied and the effects of AMR on structural characteristics, thermal stability, and in vitro cytotoxicity behaviors of the hydrogels were investigated. The findings demonstrated that hydrogels were biocompatible, although their biocompatibility decreased with decreasing molar ratio of plant oil-based monomer. The developed hydrogels can be used in many biomedical applications such as drug-delivery systems, scaffolds, lab/organ-on-a-chip, cell-culture studies and contact lenses.

\section{Acknowledgement}

The authors are grateful to Dr. Gokhan Cayli (İstanbul, Turkey), Elif Isikci Koca (İstanbul, Turkey), Seyma Turker (İstanbul, Turkey) and Necla Yucel (İstanbul, Turkey) for their support in hydrogel synthesis and characterization studies.

Ethics Committee Approval: Since the article does not contain any studies with human or animal subject, its approval to the ethics committee was not required.

Author Contributions: Concept: O.Y.C., P.C.H., Desing: O.Y.C., P.C.H., Execution: O.Y.C., P.C.H., Material supplying: O.Y.C., P.C.H., Data acquisition: O.Y.C., P.C.H., Data analysis/interpretation: O.Y.C., P.C.H., Writing: O.Y.C., P.C.H., Critical review: O.Y.C., P.C.H.

Conflict of Interest: The authors have no conflicts of interest to declare.

Funding: The authors declared that this study has received no financial support.

P., Rivarola, C.R. \& Rodriguez, N. 2019. Cytotoxicity and bioadhesive properties of poly-N-isopropylacrylamide hydrogel. Heliyon, 5(4): e01474.

4. Ding, C., Chen, X., Kang, Q. \& Yan, X. 2020. Biomedical Application of Functional Materials in Organ-on-a-Chip. Frontiers in Bioengineering and Biotechnology, 8: 823-831.

5. Dong, L.C. \& Hoffman, A.S. 1986. Thermally reversible hydrogels: III. Immobilization of enzymes for feedback reaction control. Journal of Controlled Release, 4(3): 223227. 
6. Dupé, A., Achard, M., Fischmeister, C. \& Bruneau, C. 2012. Methyl ricinoleate as platform chemical for simultaneous production of fine chemicals and polymer precursors. ChemSusChem, 5(11): 2249-2254.

7. Geckil, H., Xu, F., Zhang, X., Moon, S. \& Demirci, U. 2010. Engineering hydrogels as extracellular matrix mimics. Nanomedicine (London, England), 5(3): 469-484.

8. Guo, B., Chen, Y., Lei, Y., Zhang, L., Zhou, W.Y., Rabie, A.B.M. \& Zhao, J. 2011. Biobased poly (propylene sebacate) as shape memory polymer with tunable switching temperature for potential biomedical applications. Biomacromolecules, 12(4): 1312-1321.

9. Ilić-Stojanović, S.S., Nikolić, L.B., Nikolić, V.D., Milić, J.R., Stamenković, J., Nikolić, G.M. \& Petrović, S.D. 2013. Synthesis and characterization of thermosensitive hydrogels and the investigation of modified release of ibuprofen. Hemijska industrija, 67(6): 901-912.

10. Isikci Koca, E., Bozdag, G., Cayli, G., Kazan, D. \& Cakir Hatir, P. 2020. Thermoresponsive hydrogels based on renewable resources. Journal of Applied Polymer Science, 137(28): 48861-48870.

11. Ko, H.F., Sfeir, C. \& Kumta, P.N. 2010. Novel synthesis strategies for natural polymer and composite biomaterials as potential scaffolds for tissue engineering. Philosophical transactions. Series A, Mathematical, physical, and engineering sciences, 368(1917): 1981-1997.

12. Koetting, M.C., Peters, J.T., Steichen, S.D. \& Peppas, N.A. 2015. Stimulus-responsive hydrogels: theory, modern advances and applications. Materials Science and Engineering: R: Reports, 93: 1-49.

13. Lee, D.S. \& He, C. 2010. In-situ gelling stimuli-sensitive PEG-based amphiphilic copolymer hydrogels. pp. 123-146. In: Ottenbrite, R.M., Park, K. \& Okano, T. (eds). Biomedical Applications of Hydrogels Handbook. Springer, New York, NY, 432 pp.

14. Mantha, S., Pillai, S., Khayambashi, P., Upadhyay, A., Zhang, Y., Tao, O., Pham, H.M. \& Tran, S.D. 2019. Smart Hydrogels in Tissue Engineering and Regenerative Medicine. Materials (Basel, Switzerland), 12(20): 33233356.

15. Miao, S., Wang, P., Su, Z. \& Zhang, S. 2014. Vegetableoil-based polymers as future polymeric biomaterials. Acta biomaterialia, 10(4): 1692-1704.
16. Mohammadinejad, R., Maleki, H., Larrañeta, E., Fajardo, A.R., Nik, A.B., Shavandi, A., Sheikhi, A., Ghorbanpour, M., Farokhi, M., Govindh, P., Cabane, E., Azizi, S., Aref, A.R., Mozafari, M., Mehrali, M., Thomas, S., Mano, J.F., Mishra, Y.K. \& Thakur, V.K. 2019. Status and future scope of plant-based green hydrogels in biomedical engineering. Applied Materials Today, 16: 213-246.

17. Peers, S., Montembault, A. \& Ladavière, C. 2020. Chitosan hydrogels for sustained drug delivery. Journal of Controlled Release, 326: 150-163.

18. Peppas, N.A. \& Hoffman, A.S. 2020. Hydrogels. pp. 153166. In Wagner W.R., Zhang, G, Sakiyama-Elbert, S.E., Yaszemski, M.J., (eds). Biomaterials science, Academic Press. 1616 pp.

19. Peppas, N.A., Huang, Y., Torres-Lugo, M., Ward, J.H. \& Zhang, J. 2000. Physicochemical foundations and structural design of hydrogels in medicine and biology. Annual review of biomedical engineering, 2(1): 9-29.

20. Ribeiro, C.A., Martins, M.V.S., Bressiani, A.H., Bressiani, J.C., Leyva, M.E. \& de Queiroz, A.A.A. 2017. Electrochemical preparation and characterization of PNIPAM-HAp scaffolds for bone tissue engineering. Materials Science and Engineering: C, 81: 156-166.

21. Ruiz-Rubio, L., Álvarez, V., Lizundia, E., Vilas, J.L., Rodríguez, M. \& León, L.M. 2015. Influence of $\alpha$-methyl substitutions on interpolymer complexes formation between poly (meth) acrylic acids and poly (N-isopropyl (meth) acrylamide) s. Colloid and Polymer Science, 293(5): 1447-1455.

22. Shah, L.A., Farooqi, Z.H., Naeem, H., Shah, S.M. \& Siddiq, M. 2013. Synthesis and characterization of poly (Nisopropylacrylamide) hybrid microgels with different cross-linker contents. Journal of the Chemical Society of Pakistan, 35: 1522-1529.

23. Xu, C., Dai, G. \& Hong, Y. 2019. Recent advances in highstrength and elastic hydrogels for 3D printing in biomedical applications. Acta biomaterialia, 95: 50-59. 